\title{
Considerações sobre uma escrita habitada: Mário Cláudio e o acolhimento de outras artes'
}

\author{
Dalva Calvão \\ (Universidade Federal Fluminense)
}

\section{RESUMO}

O artigo busca, em primeiro lugar, analisar o diálogo estabelecido por três dos principais romances de Mário Cláudio com outras linguagens artísticas, a partir da observação de algumas estratégias discursivas que permitem a produtiva tradução de outros códigos pela linguagem verbal. Num segundo momento, o estudo desenvolve considerações sobre possíveis motivações que justificam o referido exercício dialógico, bem como sobre a dimensão crítica que aí se contém. Por fim, pretende-se indagar sobre a valorização da criação estética indiciada pelas escolhas temáticas e pelas práticas textuais do autor.

PALAVRAS-CHAVE: Mário Cláudio, diálogo interartes, criação estética

\section{ABSTRACT}

Firstly, the aim of this article is to analyze the established dialog among the three main novels written by Mário Cláudio with other artistic languages, trough the observation of some discoursive strategies which allow the productive translation of other codes by the means of verbal language. Secondly, this study develops concerns not only on possible motivations which justify the referred dialogic exercise, but also on its critical dimension. Finally, it intends to inquire about the aesthetic creation increase in value, signalized by the thematic choices and by the author's textual practices.

KEYWORDS: Mário Cláudio, inter-arts dialogs, aesthetic creation 
A obra de Mário Cláudio tem-se revelado como instigante possibilidade de ampliação do exercício intertextual, inscrevendo-se numa longa tradição em que o texto literário se configura como lugar de privilegiado diálogo com outras artes, do qual inevitavelmente derivam reflexões sobre o fenômeno estético, bem como indagações sobre o estatuto daquele que produz a obra de arte. Neste sentido, ocupam lugar de destaque os romances-biografias que compõem a Trilogia da Mão: Amadeo (1984), Guilhermina (1986), e Rosa (1988). Nestes livros, para além do relato sobre a vida de três artistas portugueses - o pintor Amadeo de Souza-Cardoso, a violoncelista Guilhermina Suggia e a ceramista Rosa Ramalha -, o texto se abre ao acolhimento da tarefa artística, metonimicamente representada, como indicia o título emblemático do volume em que se reúnem os três romances, na mão que trabalha a matéria-prima em busca de um resultado estético.

Dentro desta perspectiva, a leitura da trilogia, logo de saída, evidencia a utilização de procedimentos que, certamente, afirmam a referida intenção dialógica, tais como a escolha de artistas como objetos de biografias; as reproduções, nas capas e em encartes centrais, de obras e de fotos destes artistas²; a recomposição da maneira pela qual eles vivenciaram o trabalho estético, denunciando, no modo de criar, um modo de ser. Entretanto, para além destes procedimentos mais imediatamente perceptíveis, a proposta entrevista se realizará, principalmente, numa procurada correspondência entre a linguagem verbal e as diferentes linguagens de cada um dos outros artistas.

Tal correspondência pode ser inicialmente percebida na presença dos blocos narrativos que presidem a construção das três biografias e que apontam para semelhanças existentes entre essa forma de escrita e, por exemplo, algumas peças da cerâmica de Rosa Ramalha, como a que se intitula "Bicho feroz" e que se apresenta como um ambíguo ser de duas faces, organizadas como um conjunto de fragmentos em que 0 resultado final distancia-se da esperada lógica de um trabalho figurativo tradicional. Suas duas faces são, ao mesmo tempo, independentes e interligadas, oferecendo-se à fruição em variadas possibilidades, guiadas todas pela imaginação e pela interpretação do espectador, implicitamente convidado a participar de uma experiência lúdica, de que se ausentam conclusões definitivas. Esta inesperada composição, portanto, pode remeter-nos à própria estruturação dos romances, principalmente à do último - em que se narra, justamente, a vida da ceramista - com sua multiplicidade de vozes e sua aparente ilogicidade, com seus fragmentos a serem reconstruídos pela leitura, em busca de possíveis sentidos, nunca conclusivos.

Será, porém, com a pintura de Amadeo de Souza-Cardoso que a "estética do fragmento" (CALABRESE, 1988, p. 101) dos textos de Mário Cláudio mais evidenciará sua semelhança, fazendo-nos, inclusive, lembrar das relações iniciais entre a literatura e a pintura à época do surgimento do cubismo, quando as concepções de decomposição da realidade em figuras geométricas desenvolvidas pelos pintores sofreram influências diretas das ideias de Apollinaire. No ambiente das vanguardas do século $X X$, em que se intensificaram as trocas de experiências entre os artistas de várias linguagens, em busca de renovações estéticas, o cubismo, termo inicialmente aplicado à pintura, estendeu-se também a um tipo de poesia 
que buscava a representação da realidade através de planos simultâneos e superpostos cujo efeito de fracionamento tornava-se inevitável. O texto de Mário Cláudio parece evocar esta relação inicial ao se aproximar dos quadros do pintor de Amarante, mesmo quando esta aproximação se dá com aqueles em que, atenuada uma configuração geométrica mais rígida, permanece a técnica de colagens e superposições, onde os objetos, ainda que emoldurados como um conjunto, mantêm sua individualidade-como podemos observar em "Entrada", espécie de reunião de figuras díspares, desorganizadamente espalhadas sobre uma superfície. A opção por esta construção tem, evidentemente, outras implicações, o que justifica sua manutenção também em Guilhermina. Contudo, outras possíveis intenções não impedem a constatação das semelhanças entre a estrutura dos romances e a estrutura de obras do pintor e da ceramista, em um movimento que promove a interação dos seus diversificados códigos estéticos.

O diálogo assim instaurado será intensificado, entretanto, em uma dimensão mais interna, na elaboração do próprio tecido verbal, que vai incorporando marcas relativas ao material e ao conteúdo com que trabalham os outros artistas. A linguagem utilizada em Amadeoestruturase, desta maneira, como uma linguagem fortemente plástica, em que todo um campo semântico relacionado ao visual é permanentemente acionado para a recriação de paisagens, de cenários, de elementos que nos direcionam para o mundo das vivências e das telas de Amadeo de Souza-Cardoso. Destas, algumas são de fato retomadas pela palavra do escritor. Mas, o que, antes disto, se evidencia é uma correspondência mais sutil entre o texto e a pintura, é a insistência do texto em revelar o mundo do pintor como se o estivesse fazendo através dos olhos daquele, na captação essencial de cores, de formas, de sugestões pictóricas, de pequenos detalhes que formam o desenho de uma realidade possivelmente muito próxima à da experiência de Amadeo, em sua condição de "vidente" privilegiado, a se abrir para o mundo pelo olhar, como ensina Merleau-Ponty: "Imerso no visível por seu corpo, embora ele próprio visível, o vidente não se apropria daquilo que vê: só se aproxima dele pelo olhar, abre-se para o mundo". (MERLEAU-PONTY, 2004, p. 16). Independentemente do fato de sabermos que muito desse desenho estará impregnado pela memória ou pela imaginação do próprio escritor, o que pretendemos ressaltar é a aparente disposição do texto em se constituir, frequentemente, como uma tela, em que impressões visuais se vão transformando em composições plásticas, como podemos observar, a título de exemplo, na passagem em que se relata a preparação da exportação do vinho, produzido na propriedade da família do pintor, a Casa de Manhufe, o qual, em seu longo percurso desde Vila Meã, deveria chegar aos navios que o transportariam ao Brasil. Em sua infância, Amadeo assistia ao preparo desta demorada viagem e em sua imaginação descortinava-se o destino a que iriam dar os barcos:

E vendo embalar os pipos, desveladamente enfiados em seus invólucros de pau, cismava Amadeo nessa costa distante e vermelha, coroada de penas coloridas. As bestas do mato, de pêlo fulvo ou pintalgado, numa clareira entre as ervas altas se reuniam. E o resto era um 
céu invisível de guinchos e grasnidos, flores de corola palpitante, frutos que se esmagavam numa chapola de fibra madura. (CLÁUDIO, 1986, p. 24).

O transporte do vinho serve, pois, de pretexto para que se registre a atenção visual do futuro pintor, a atração pelas cores e formas, que the possibilitava, auxiliado certamente por informações sobre a paisagem tropical, compor o minucioso cenário imaginário, como se estivesse, por meio de um invisível pincel, transpondo-o para uma tela, exercitando desta forma o poder de reconstrução de espaços e de transporte a infinitas distâncias originado da capacidade da visão: "É preciso tomar ao pé da letra o que nos ensina a visão: que por ela tocamos o sol, as estrelas, estamos ao mesmo tempo em toda parte [...], e que mesmo nosso poder de imaginarmo-nos alhures [...], esse poder recorre ainda à visão, reemprega meios que obtemos dela". (MERLEAU-PONTY, 2004, p. 43)

Esta aguda capacidade, própria dos que captam o mundo pelo olhar, aqui se terá manifestado, antes, no próprio escritor que, através da onisciência do narrador ao relatar aquilo que a personagem imagina, cria a atmosfera visual adequada para a revelação da subjetividade do pintor, estabelecendo a desejável rede entre a escrita e a linguagem pictórica, criando, enfim, com as palavras, quadros, como se, pelo entrelaçamento de linguagens, ele pudesse olhar com os olhos de Amadeo.

Semelhante processo ocorre na narrativa sobre a vida de Rosa Ramalha que, como Amadeo, absorve visualmente o mundo, fazendo do olhar uma ponte para o conhecimento das infinitas formas que a cercam e que por ela serão recriadas nas dobras do barro. Os detalhes, as formas, as cores, os volumes, os elementos fantásticos, os fatos do cotidiano que desenham o extraordinário mundo de Rosa se implantam nas frases e nas imagens do livro, na representação de um espaço que parece filtrado pelos olhos da ceramista, desde sempre ocupados em registrar, nas mínimas particularidades, tudo que se lhes depara:

Pela beira do caminho atentava na folhagem trepadora, na lagartixa que, por entre ela, se esgueirava, nos bagos que principiavam a pintar. Escalava os degraus da soleira, pousava o nariz no mármore do balcão, a estudar o que via. Patinhavam meninos semi-nus, junto aos sacos, de camisola encardida, a guinchar desesperadamente, agarrados à pilinha. Da parte de cá barafustavam os homens, de chapéu derrubado, a desferir fortes palmadas no peito uns dos outros. Tragavam o vinho, faziam subir e descer, de erguido gargomilo, a dura maçã-de-Adão, devolviam a malga, tingida de borra roxa que, em lágrimas, escorria pelo vidrado fendido. $\mathrm{O}$ encanto maior, porém, eram os frascos enormes, perfilados lá por trás, de confeitos coloridos, à espera de que os tomasse o tendeiro, a gestos muito lentos lhes desatarraxasse a tampa, recitasse o número que the requeriam. (CLÁUDIO, 1988, p. 17) 
Nesta cena, que se inclui no relato de uma ida de Rosa, ainda criança, à venda da aldeia, como em muitas outras, o olhar da personagem, como uma câmera lenta, passa de objeto a objeto, captando aquilo que define cada um deles, como a armazenar nos arquivos da memória o material com o qual alimentará sua criação. Tal movimento é, inegavelmente, idêntico ao realizado pelo pintor, em sua procura pela "irradiação do visível": "É essa animação interna, essa irradiação do visível que o pintor procura sob os nomes de profundidade, de espaço e de cor". (MERLEAUPONTY, 2004, p. 38). E torna-se desnecessário lembrar que aquilo que resulta da observação de Rosa só pode ser por nós visualizado por ter sido recriado pelo texto que, como uma lente maior, capta o olhar da menina e o que ela vê, constituindo-se como um espelho que nos dá acesso à realidade da ceramista e nos envolve na "armadilha desse jogo de olhares" (PESSANHA, In: NOVAES, 1988, p. 9, p. 50), no qual o olhar do leitor se debruça sobre o olhar do escritor, que se debruça sobre o olhar da personagem que, por sua vez, olha o mundo. E aqui, como em Amadeo, para além da suspeita sobre que elementos nessa composição de cena pertenceriam à memória ou à invenção do escritor, expõe-se a correspondência entre a linguagem verbal e a linguagem plástica, em intersecções semióticas que ampliam as fronteiras do texto, fazendo-o participar do universo da pintura e da cerâmica, inventando-se em tela pintada, ou em barro moldado.

$\mathrm{Na}$ configuração desse resultado, no entanto, o autor deixa marcadas as diferenças entre as experiências de vida e as características culturais que atravessam as obras dos dois artistas. Desta forma, a linguagem utilizada em Amadeoé perfeitamente adequada ao seu nível social e cultural, constituindo-se como uma linguagem elaborada, culta, às vezes difícil, tendendo a um preciosismo da forma, com suas palavras raras e torneios frasais, em que se revela o domínio e o rigor da forma, exatamente como acontece nos elaborados quadros de Amadeo de Souza-Cardoso. Já em Rosa, os narradores se utilizam frequentes vezes de uma linguagem mais cotidiana, compatível com o universo pelo qual transitam, repleta de termos coloquiais ou de palavras próprias às atividades rurais que exercitam. Algumas vezes, ao relatarem falas de Rosa Ramalha, revelam o uso espontâneo e popular da língua, em expressões às vezes rústicas, nas quais se destacam traços do humor que sustenta a visão carnavalesca depreendida de muitas das peças da ceramista. Assim, embora neste volume se mantenha a mesma voltagem poética dos outros, o autor parece interessado em trazer para o texto as características da linguagem da aldeã Rosa, criando mais uma possibilidade de correspondência entre a sua palavra e a obra da artista, como já fizera em relação à obra do pintor de Manhufe.

Em Guilhermina, a linguagem, como em Amadeo, será predominantemente trabalhada em sua dimensão culta, elevada, de vocabulário cuidado, de imagens exigentes, o que igualmente pode ser percebido como uma possível correspondência entre o texto e a arte a que se dedicou Guilhermina Suggia, que, também de outras maneiras, será lembrada pelo texto. Assim, se no primeiro romance a linguagem remetia-nos ao plástico, neste segundo livro ela estará, muitas vezes, relacionada a elementos sonoros, procurando evocar, através dos signos verbais, o ambiente musical em que se movimentava a artista. Parece- 
nos que isto se dará, antes de tudo, pela própria musicalidade do texto, por sua sonoridade modulada pelas sequências de frases dispostas com o movimento e o artifício de uma partitura barroca, em suas inversões e repetições. Poder-se-ia argumentar que essa musicalidade não é uma exclusividade desse romance, mas uma marca do discurso do autor, presente inclusive nos dois outros volumes da trilogia enfocada, nos quais a insistência ao apelo visual não exclui o ritmo musical da frase. Em Guilhermina, entretanto, essa sonoridade adquire uma conotação suplementar, associando-se imediatamente à experiência da personagem e tornando significativos os vínculos entre a linguagem verbal e a linguagem musical, vínculos estes que vão, certamente, além dessa musicalidade frasal e que se revelam nas situações discursivas em que a sonoridade aparece explicitamente referida, compondo para a violoncelista um espaço próprio, no qual ela aparece envolvida pela matéria essencial de sua arte. De forma emblemática, este recurso pode ser observado na abertura do romance, quando toda a paisagem aparece dominada pela "estranha voz" dos sinos das igrejas de São Francisco e de São Nicolau, no Porto, que tocam compassadamente, desenhando uma moldura musical para a primeira visita da personagem à cidade: "Com tal concerto quisemos dar início à história de Guilhermina, que com pouco mais de seis anos vai hoje a baptizar". (CLÁUDIO, 1986b, p. 11).

A vida da concertista será por esses "campos sonoros" definitivamente marcada, "por seu voo e sua densidade, sua lição de áreas delimitadas e tarefas repetidas" (CLÁUDIO, 1986b, p.11). A impressão sonora e sua ampliação se inscrevem em sua memória, sugerindo uma possibilidade de ordenação do mundo, uma forma de lhe compor um sentido: "Atrasam-se os carrilhões na memória que lhes assiste, órgão gigantesco ordenando o caos, dando corpo a aglomerados que os homens compõem." (CLÁUDIO, 1986b, p. 11). À ordenação entrevista destinam-se os sons esparsos e independentes que povoam a cidade, complexo universo sonoro para o qual se admite desde logo a destinação da futura musicista: "O seu é o trecho que já está escrito, que no desferir das cordas se descobre, nas arestas em que a música se debate e o céu fica coalhado de cirros amarelos." (CLÁUDIO, 1986b, p. 11). Os sinos parecem, deste modo, assinalar um duplo batismo, o segundo deles nesta espécie de crença religiosa em que se traduz a entrega total à música. Sobre eles recai a interrogação do narrador, ao surpreender a concertista em Paris, à época de escolhas sobre os caminhos profissionais: "Que pensará, no crepúsculo, como se da Vila Molitor não houvesse escapatória [...]? Ouvirá acaso os sinos do Porto, na manhã abafada de nevoeiro mortífero?" (CLÁUDIO, 1986b, p. 41). E, ao término do percurso existencial da artista, os sons originais dos mesmos sinos serão novamente invocados, na confessada estratégia narrativa que se reveste de mal disfarçada homenagem: "Por ela fiz repicar os sinos do Porto, os de São Francisco e os de São Nicolau". (CLÁUDIO, 1986b, p. 116). O mesmo concerto, pois, abre e fecha o relato sobre a vida da Guilhermina Suggia, associando a escrita à música e sugerindo, nesta associação, a idêntica possibilidade de repetição e de permanência contida tanto em uma, quanto em outra.

O transporte à musicalidade inerente à vida de Guilhermina ficará 
igualmente visível nas cenas que a relembram em plena criação interpretativa, ou na poética e comovente descrição do dedilhar final sobre o lençol, quando, rigorosamente, é aberto um espaço no código gráfico verbal para a transcrição do código gráfico musical. As diversas alusões às possibilidades musicais do violoncelo e ao processo de aprendizagem para dominá-lo, bem como ao isolamento que daí resultava, também nos remetem ao permanente envolvimento da artista pelo ambiente que se organiza a partir das percepções auditivas, em direção à construção de um território que lentamente se afasta do concreto, abrindo outras dimensões a quem nele escolher habitar, na progressiva intimidade com esta linguagem "aquém do mundo e do designável" (MERLEAU-PONTY, 2004, p. 15):

Eis que Bach assujeitava a vida, com suas pautas onde um firmamento se sintetizava, passavam geométricos e sem desvio os corpos, era só um infinito expandido, galáxias e meteoros, sobre luzes e mais luzes, outro além. E o espectro do rigor superlativo, a conclusão de que coisa nenhuma sobejava, logo ali se lhe impunham. "Nada do que se tocasse", aduziria ela, "poderia acrescentar fosse o que fosse." (CLÁUDIO, 1986b, p. 39)

Confundem-se nesta passagem a experiência da violoncelista e a do próprio escritor, como já ocorrera em relação à percepção visual do pintor e da ceramista. Nesta biografia em que, como nas outras, a invenção preenche as lacunas referenciais, a compreensão do fenômeno musical, sintetizado na admiração pela obra de Bach, que o texto atribui a Guilhermina, constitui-se pelo filtro da imaginação e da sensibilidade do autor. E será justamente por meio desta possibilidade do escritor compreender e expressar a experiência de outro, que a escrita se fará veículo de impressões sonoras, traduzindo em palavras a vivência extremamente subjetiva proporcionada pelo abstrato universo da música.

Neste sentido, a tradução não significa simplesmente a transposição de uma outra linguagem em matéria verbal, mas a experiência que procura captar o que se constitui como essencial à outra arte, para, a partir daí, recriar a realidade. Tal processo parece ocorrer nas situações apontadas, em que o texto busca incorporar os elementos fundamentais das outras linguagens, em referências explícitas e recriações discursivas passíveis de trazerem ao leitor as marcas e a atmosfera da percepção plástica ou musical. Contudo, a especificidade dessa tradução se faz mais visível quando a escrita explicitamente se apropria de algumas obras de Amadeo de Souza-Cardoso ou de Rosa Ramalha, reproduzidas no encarte central dos livros, para reapresentá-las sob a forma de construções verbais: assim, os quadros de Amadeo, "Casa de Manhufe" e "Cozinha da Casa de Manhufe" (CLÁUDIO, 1986, p. 11, 12, 60, 62) passam a apresentar uma espécie de dupla existência e de dupla permanência: continuam a ser as inconfundíveis telas do pintor, mas são, também, uma casa e uma cozinha inventadas pela imaginação ou reconstruídas pela memória de Mário Cláudio. Poderíamos observar o mesmo procedimento nas releituras de "Oceano Vermelhão Azul Cabeça Azul" (CLÁUDIO, 1986, p. 95), "Janelas de Pescador" e "A Casita Clara - Paisagem"(CLÁUDIO, 1986, 
p. 99), "Auto-retrato" (CLÁUDIO, 1986, p. 105): as descrições que aí lemos são, certamente, as dos quadros que vemos nas reproduções. Mas são, igualmente, a interpretação que deles fez o autor do romance, a forma como, subjetivamente, seu olhar os captou, como se depreende do trecho que traduz os quadros "Entrada" e "Pintura":

Arrumam-se em distintivos as certezas, pêras ou aracnídeos, cigarros ou espelhinhos de bolso, siglas de um pacto com a criação. E a paz se espraia por lâminas de tinta rugosa, madeiros de instrumentos de corda, verberações do giz ao giz sobreposto. Decalcadas, desenham as letras o rótulo da verdade total, e nada falta senão o repouso, nada existe, nem o sofrimento nem o prazer, nem o instinto de articular palavras, que é por si só alfabeto a interpretar. (CLÁUDIO, 1986, p. 107).

Assim dispostas, as palavras do autor também se oferecem como "siglas de um pacto com a criação", revelando a estatura particular do texto, a marca comum que o aproxima da criação do pintor, não para explicá-la, mas para, a partir dela, propor a abertura de novos sentidos. Deste modo, o que aí encontramos, como em outras inúmeras passagens dessa trilogia, longe está de se configurar como mera transposição verbal de uma obra não verbal, o que, segundo Claus Clüver, caracterizaria o que comumente se denomina ekphrasis e que designa uma "forma de reescrita", na qual se incluem procedimentos que vão desde "a descrição de uma estátua ou de uma catedral num livro de história da arte" até a "apresentação verbal de uma litografia no catálogo de um leilão" (CLÜVER, 1997, p. 42).

No interior desse amplo procedimento, o pesquisador destaca a existência de "ekphraseis literárias", algumas das quais tendem igualmente a uma autonomia em relação à obra a que se referem, permitindo que o leitor dispense o original, mesmo que apenas em sua evocação mental. Isto não aconteceria, entretanto, com "uma forma especial de reescrita 'ekphrástica', na qual o texto literário oferece uma reconstrução interpretativa de um texto não-verbal", (CLÜVER, 1997, p. 42), prática que Clüver designa como "tradução intersemiótica", considerando-a um caso mais restrito da "transposição intersemiótica":

Pode-se considerar todas as formas de ekphrasiscomo transposições intersemióticas, ao passo que o conceito de "tradução intersemiótica" soa melhor se restringido a textos (em qualquer sistema sígnico) que, em primeiro lugar, oferecem uma reapresentação relativamente ampla (mesmo que jamais completa) do texto-fonte composto num sistema sígnico diferente, numa forma apropriada, transmitindo certo sentido de estilo e técnica e incluindo equivalentes de figuras retóricas; e, em segundo lugar, que acrescentem relativamente poucos elementos, sem paralelo no texto-fonte.(CLÜVER, 1997, p. 43). 
Nesta definição poderíamos situar a reescrita empreendida por Mário Cláudio das obras de seus biografados, considerando-se que o mesmo procedimento apontado em Amadeo se repete em Rosa, onde obras como "Menina dos pombos", "Poeta de Leça", "Macaco", "Rei", são retomadas pelo texto. Em ambos os casos, assistimos a uma "reconstrução interpretativa de um texto não-verbal", através de uma 'reapresentação relativamente ampla do texto-fonte", ao qual apenas alguns elementos são "acrescentados". As reproduções gráficas das obras reforçam o caráter de "tradução intersemiótica", evitando que o leitor se distancie do "textofonte", mantido à vista para que as comparações sejam possíveis e o processo de tradução mais amplamente percebido. E se esta presença imediata não se dá em Guilhermina, tal não nos impede de aí percebermos o mesmo trabalho de reconstrução interpretativa, podendo o leitor, a qualquer tempo, pela audição das peças, igualmente comparar o texto verbal com o texto musical que lhe serviu de fonte. Em nenhum momento, ao se referir às execuções da artista, o autor empreende uma simples descrição ou uma espécie de explicação sobre a peça a que se refere. Sirva-nos de exemplo o último trecho transcrito do livro sobre a concertista, onde vemos uma tradução intensamente poética do que se pode sentir ouvindo as ítes de Bach para violoncelo. Semelhante processo pode ser percebido em relação ao rondó do "Concerto em Ré" de Haydn, apresentado como a melodia que insistentemente volta à memória da concertista - "Persiste o rondó, embalando os que vão, os sentidos revolvendo de Guilhermina" -, terminando por se impor inteiramente por sobre os ruídos que entrecortam o percurso de uma viagem de trem: "Num estrépito, porém, de rodados e cabos, a um ramal se acede, apodera-se a orquestra da integral melodia. E lá vai Joseph Haydn, fungando rapé, a luz soprando de um astro, alumiando outro, numa pressa transitando pela Via Láctea." (CLÁUDIO, 1986b, p. 65). O que aí assistimos é à transposição, para os signos verbais, do movimento e da energia da música de Haydn, num trabalho de tradução que parece fazer repercutir no próprio movimento do texto o caráter "andarilho e folgazão" (CLÁUDIO, 1986b, p. 65) da peça relembrada, fazendo-nos pensar na possibilidade de "um sistema de equivalências" (MERLEAU-PONTY, 2004, p. 38) entre os elementos que sustentam as diferentes criações estéticas, na esteira de reflexões que têm, há muito, acompanhado as indagações sobre o fenômeno artístico.

Nesta direção, parece-nos inevitável, em primeiro lugar, invocar a teoria das correspondências de Baudelaire, para quem, na base de qualquer atividade artística, estaria presente uma ideia de analogia, que nos permitiria sempre traduzir uma linguagem em outra: "[...] seria na verdade surpreendente que o som não pudesse sugerir a cor, que as cores não pudessem dar a idéia de uma melodia, e que o som e a cor fossem impróprios para traduzir idéias, sendo as coisas sempre expressas por uma analogia recíproca [...]." (BAUDELAIRE, 1990, p. 39). Entretanto, a formulação do poeta está presa a uma determinada concepção filosófica de caráter idealista, em que o mundo se configura como uma infinita rede de analogias, como defendeu, à época, o movimento empreendido pelos românticos, em retomada de conceitos vindos de períodos muito anteriores: "A idéia da correspondência universal é provavelmente tão 
antiga quanto a sociedade humana. É explicável: a analogia torna o mundo habitável." (PAZ, 1984, p. 93). Será nesta corrente que se incluirá, a seu modo, o pensamento de Baudelaire, para quem "o sistema do universo é o modelo da criação poética" (PAZ, 1984, p. 97), atribuindo à arte, por sua capacidade de repetir a ideia de perfeição percebida no universo, uma possibilidade de refúgio para a limitação humana.

Embora em tudo isto permaneça certo fascínio e o poeta das Flores do Malseja sempre referência quando falamos em diálogos interartes, as ideias de correspondências percebidas nos romances de Mário Cláudio não parecem apontar na direção de uma analogia universal. Em consonância com formulações atuais, distantes de qualquer "substrato místico das correspondências" (JUNQUEIRA, 1985 p. 60), o que lemos em suas biografias ficcionais parece se configurar como uma subjetiva indagação sobre traços comuns que sustentam qualquer atividade estética, promovendo um silencioso, porém inevitável diálogo entre elas, e permitindo que aquele que se debruce sobre uma forma artística acabe frequentemente por se voltar também para as outras, no inquieto questionamento sobre suas comuns motivações, ou na procura e no entendimento daquilo que Gilles Deleuze, ao analisar a obra de Proust, chamou de "signo da arte".

Em capítulo intitulado "Os signos da arte e a essência", Deleuze começa por levantar a questão da superioridade dos signos da arte sobre os outros, e afirma que esta superioridade existe pela imaterialidade dos primeiros, em oposição à materialidade dos segundos. Segundo ele, "os outros signos são materiais, não apenas por sua origem e pela maneira como permanecem semi-encobertos no objeto, mas também por seu desenvolvimento ou sua 'explicação'. A Madeleinenos remete a Combray, o calçamento a Veneza [...]" (DELEUZE, 1987, p. 40). Desta forma, sempre descobrimos o sentido de um signo em outra coisa, subsistindo, nessas operações, um resto de matéria, "rebelde ao espírito". Ao contrário disto, "a Arte nos dá a verdadeira unidade: a unidade de um signo imaterial e de um sentido inteiramente espiritual. A essência é exatamente essa unidade do signo e do sentido, tal qual é revelada na obra de arte". (DELEUZE, 1987, p. 42) A essência assim revelada "é uma diferença, a Diferença última e absoluta", oposta a uma diferença empírica e extrínseca, e se manifesta como "a presença de uma qualidade última no âmago de um sujeito", de onde se deduz que "não é o sujeito que explica a essência, é, antes, a essência que se implica, se envolve, se enrola no sujeito. Mais ainda: enrolando-se sobre si mesma ela constitui a subjetividade". (DELEUZE, 1987, p. 43).

E se a essência só se revela através da obra de arte, esta se torna a única forma possível de uma comunicação mais verdadeira, já que "nossas únicas janelas, nossas únicas portas são espirituais: só há intersubjetividade artística" (DELEUZE,1987, p. 42). Portanto, o que a arte possibilita, ultrapassando a exigência de um referente, vai em direção a alguma coisa imaterial e essencial. Por esta razão, estabelece-se, entre aquele que a realiza e o que a recebe, uma identidade subjetiva, que permite ao segundo, indo além da matéria concreta de que se construiu o trabalho artístico, sentir a ideia fluida, espiritual, subjetiva que o habita: 
Como a essência se encarna na obra de arte?[...] Ela se encarna nas matérias. [...]. Essas matérias, sem dúvida, são a cor para o pintor [...], o som para o músico e a palavra para o escritor. Mas, de modo mais profundo, são matérias livres que tanto se exprimem através das palavras, como dos sons e das cores. [...] O verdadeiro tema de uma obra não é o assunto tratado [...], mas os temas inconscientes, os arquétipos involuntários, dos quais as palavras, como as cores e os sons, tiram o seu sentido e a sua vida. A arte é uma verdadeira transmutação da matéria. Nela a matéria se espiritualiza, os meios físicos se desmaterializam, para refratar a essência, isto é, a qualidade de um mundo original. (DELEUZE, 1987, p. 47)

Se a percepção de tal fenômeno e a comunicação daí originada pode-se dar entre o produtor e o receptor considerado comum, possivelmente se fará mais intensa se este receptor for também um artista, conhecedor, por experiência própria, do poder revelador e comunicativo da obra. Se sua arte, na imaterialidade de seu signo, e independentemente da matéria de que se serve, é capaz de revelar a sua "qualidade última", o mesmo poderá por ele ser percebido nas obras de outros artistas, sobre as quais poderá debruçar-se, provavelmente certo de que as "qualidades últimas", por elas reveladas, mantêm um secreto diálogo não só com sua própria essência, mas com as secretas qualidades últimas de incontáveis e desconhecidos seres humanos, que com as "matérias livres" contidas em cada manifestação estética se identificam. Nesta linha de pensamento julgamos poder, talvez, incluir o que chamamos de diálogo entre o texto de Mário Cláudio e as realizações de seus biografados: como uma poética tentativa de mergulhar sempre mais no imaterial "signo da arte", para, através dele experimentar uma maneira especial de se entender o mundo, buscando, quem sabe, como foi dito sobre a música na biografia de Guilhermina, uma forma para "ordenar o caos" (CLÁUDIO, 1986b, p. 11).

Para além dessas questões, podemos ainda observar que a dimensão intersemiótica da trilogia biográfica de Mário Cláudio apresenta outra possibilidade: a de se constituir como um texto crítico sobre as obras dos artistas que são objetos de sua escrita. Ao falarmos em texto crítico, porém, não nos estamos referindo a atitudes valorativas, à emissão de julgamentos sobre as obras examinadas, mas a uma atitude de reflexão que, feita por dentro da narrativa, constituir-se-á em alimento para esta mesma narrativa. E ao fazermos esta afirmativa, temos em mente alguns aspectos da abordagem crítica proposta pelos poetas românticos alemães, segundo a análise de seu pensamento empreendida por Walter Benjamin. Em sua dupla atividade de criadores e críticos, Schlegel e Novalis criaram uma teoria na qual a arte é considerada a atividade reflexiva por excelência, o ponto de partida e o meio essencial para que a reflexão se desdobre em reflexão, infinitamente, criando uma também infinita possibilidade de renovação de conhecimentos. Para eles, a arte é, não apenas o ponto indiferenciado de onde nasce a reflexão, mas a atividade humana mais semelhante ao ato mesmo da reflexão, sendo, portanto, uma atividade 
inesgotavelmente geradora de outras reflexões. Por isto, Novalis afirma: "A arte da poesia é certamente uma utilização arbitrária, ativa e produtiva dos nossos órgãos - e talvez o pensar seria ele mesmo algo não muito diferente-e, portanto, pensar e poetar constituiriam uma mesma coisa". (Apud. BENJAMIN, 1993, p. 73).

Se tal dimensão conferiram os românticos alemães à poesia, alçada à condição máxima de forma por excelência de conhecimento do mundo, torna-se compreensível que tivessem eles dado à crítica de arte um estatuto semelhante, já que esta se caracterizaria por ser o exercício de reflexão sobre a atividade que se define como a própria reflexão. A crítica de arte passa a ser, portanto, um desdobrar-se da obra de arte, numa inesgotável possibilidade de interpretações e conhecimentos: "Crítica é, então, como que um experimento na obra de arte, através do qual a reflexão desta é despertada e ela é levada à consciência e ao conhecimento de si mesma" (BENJAMIN,1993, p. 74). Por outro lado, uma obra de arte só se definirá como tal, se contiver em si os elementos suscitadores, provocadores da crítica. O critério de julgamento da obra dentro dos padrões clássicos de um ideal artístico estará, assim, afastado. A obra de arte, ao conter em si uma ideia da arte - o "medium" de reflexão infinitamente gerador de outras reflexões -, não encerra, ou persegue, um determinado ideal pré-concebido. Para Schlegel e para Novalis, a atividade crítica será sempre uma atividade positiva, na medida em que, ampliando os sentidos de uma obra singular, aponta para a qualidade fundamental da arte, que é sua infinitude. Portanto, a crítica de arte se caracterizaria como um desdobramento de uma obra, e não como um julgamento de valor. Tal desdobramento resulta, afinal, em um trabalho muito próximo ao trabalho estético inicial, configurando-se como uma atividade igualmente criativa. $\mathrm{O}$ crítico, nesta perspectiva, adquire $\mathrm{O}$ estatuto de poeta e o melhor crítico será o próprio poeta:

Está claro: para os românticos, a crítica é muito menos o julgamento de uma obra do que o método de seu acabamento. Neste sentido, eles fomentaram a crítica poética, superaram a diferença entre crítica e poesia e afirmaram: "A poesia só pode ser criticada pela poesia." Um juízo de arte que não é ao mesmo tempo uma obra de arte, [...] não possui nenhum direito de cidadania no reino da arte. "Essa crítica poética [...] exporá novamente a exposição, desejará formar ainda uma vez o já formado [...], irá completar a obra, rejuvenescê-la, configurá-la novamente" (BENJAMIN, 1993, p. 77).

Os poetas estudados por Benjamin não se referiam explicitamente a uma crítica que fosse realizada dentro de outra obra de arte, mas a uma crítica que fosse ela mesma poética, que partilhasse do estatuto gerador da obra criticada. Mas a teoria por eles pensada abriu caminho para atitudes e reflexões que se tornaram frequentes no percurso da arte e da crítica, inaugurando ou intensificando a consciência sobre o caráter artístico da crítica, sobre a adequação crítica do poeta e, por extensão, do artista de modo geral, bem como sobre a possibilidade de a obra de arte se constituir como inesgotável matriz, jamais completamente 
acabada, sempre passível de ser retomada e recriada, a partir do texto crítico, mas, igualmente, no corpo mesmo de outras obras. Ao retomarmos as ideias dos primeiros românticos, parece-nos possível estabelecer ligações entre as suas teorias e as reivindicações contemporâneas de estatuto literário para o texto crítico, de indefinição de fronteiras entre o texto literário e o texto ensaístico, a partir de uma justa percepção da raiz comum que os une. A discussão sobre a comum configuração criativa que aproxima a atividade do crítico e a do artista se mantém em aberto, apontando para possíveis ampliações da questão, ao admitir o diálogo e a crítica interartes.

Neste percurso incluímos a dimensão crítica da obra de Mário Cláudio. Diluindo as fronteiras entre o trabalho de criação e o trabalho crítico, ele faz de seu texto um espaço para a "crítica poética" de que fala Walter Benjamin, produzindo, como queriam os poetas alemães, "um juízo de arte" que é "ao mesmo tempo uma obra de arte". Este "juízo de arte", entretanto, não parte de critérios de valor baseados em conceitos préestabelecidos, mas se constitui como tal pelo próprio ato de refletir sobre outra obra. A reflexão é sinônimo desse juízo, pois ela indicia uma aproximação subjetiva com o que foi percebido como abertura à reflexão na obra tomada como ponto de partida. Assim constituída, esta crítica poética "irá completar a obra, rejuvenescê-la, configurá-la novamente", refletir sobre o que já é reflexão, ampliar a cadeia que, no dizer daqueles poetas, seria infinita. Ao pensar sobre as produções de Amadeo de SouzaCardoso, Guilhermina Suggia e Rosa Ramalha, retomando-as e traduzindo-as, a partir delas compondo seus romances, Mário Cláudio intensifica o potencial reflexivo dessas obras, amplia significações latentes, possibilitando, por extensão, novas reflexões sobre a arte de modo geral e sobre aqueles que a realizam: "A crítica da obra é muito mais sua reflexão, que, evidentemente, pode apenas levar ao desdobramento do germe crítico imanente a ela mesma" (BENJAMIN, 1993, p. 85).

Dentro desta perspectiva, os romances de Mário Cláudio permitem uma indagação de caráter mais abrangente, que diz respeito ao lugar da arte no âmbito das atividades humanas: o fato de um escritor se ocupar tão frequentemente de outros artistas, expondo minuciosamente aspectos ligados aos seus processos de criação e ao modo como cada um deles se relaciona com a matéria-prima utilizada, parece apontar para uma insistente indagação sobre as causas ou sobre o sentido mais interno dessa forma de atividade. Várias poderiam ser as respostas para tal questionamento: o mistério que move o homem para a criação, apesar de insistentemente interrogado, continua sem resposta definitiva. Mas algumas das tentativas de explicação são extremamente válidas, como a reflexão desenvolvida por Hannah Arendt: ao expor e analisar o percurso histórico das relações do homem com o trabalho, a filósofa alemã estabelece uma distinção entre labor e trabalho. Segundo ela, o labor estaria ligado à fundamental necessidade humana de sobrevivência, à luta para vencer as forças da natureza, ao infindável esforço para garantir sua vida no planeta, limpando, plantando, colhendo, defendendo-se da chuva ou do sol, protegendo-se, cuidando de animais. O labor é interminável e repetitivo, pois não tem durabilidade: recomeça a cada dia, a cada mês, a cada estação, a cada vitória dos fenômenos atmosféricos. Se as conquistas materiais mudaram a face do labor, não significa que 
ele não continue aprisionando o homem em sua infindável exigência de tarefas inadiáveis. Em oposição a esta atividade básica, sem a qual, no entanto, não sobreviveríamos, Hannah Arendt invoca o trabalho, a atividade da qual resultam as coisas fabricadas pelo homem, os objetos de seu dia a dia, os inúmeros utensílios criados para que a vida se torne não apenas possível, mas, em princípio, melhor: "O trabalho de nossas mãos, em contraposição ao labor do nosso corpo [...] fabrica a infinita variedade de coisas cuja soma total constitui o artifício humano". (ARENDT, 1993, p. 90).

Os artifícios originados do trabalho, ao contrário das ações determinadas pelo labor, são destinados a durar, e esta durabilidade pode ultrapassar o tempo de vida do próprio homem, o que confere a eles o poder de suscitar a sensação de segurança e de estabilidade, de dar aos homens a certeza, ao menos temporária, de sua permanência, tornando o mundo objetivo e, portanto, menos ameaçador: "[...] contra a subjetividade dos homens ergue-se a objetividade do mundo feito pelo homem, e não a sublime indiferença de uma natureza intacta, cuja devastadora força elementar os forçaria a percorrer inexoravelmente o círculo do seu próprio movimento biológico [...]." (ARENDT, 2003, p. 150).

Após a análise de como essas coisas duráveis foram, ao longo dos tempos, tratadas pelo homem, adquirindo cada vez mais importância nas sociedades construídas sobre ideias de utilitarismo, reificação, troca e valores, a autora chega às considerações sobre um tipo de trabalho que, ultrapassando as exigências do utilitarismo, mantém o estatuto básico de artefato fabricado pela mão do homem, remetendo-nos à consoladora ideia de durabilidade e de permanência e oferecendo-nos um refúgio, não só para o incansável labor, mas para as possíveis distorções que o trabalho comum possa vir a sofrer. Este tipo de trabalho, do qual derivam "objetos estritamente sem utilidade", (ARENDT, 2003, p. 180) é a atividade artística:

Assim, a durabilidade das obras de arte é superior àquela de que todas as coisas precisam para existir; e, através do tempo, pode atingir a permanência. [...] É como se a estabilidade humana transparecesse na permanência da arte, de sorte que certo pressentimento de imortalidade - não a imortalidade da alma ou da vida, mas algo imortal feito por mãos mortais - adquire presença tangível para fulgurar e ser visto, soar e ser escutado, escrever e ser lido. (ARENDT, 2003, p. 181)

Esta seria, parece-nos, uma explicação possível para a atração que o trabalho artístico continua a exercer sobre os homens. Na arte, o homem redimensiona sua relação com a vida, conseguindo uma forma própria de exercitar sua potência criativa. É nela que, fundamentalmente, como explicitou Hannah Arendt, se desenha a possibilidade da durabilidade e da permanência, forma talvez única de se ultrapassar o sentimento de finitude. Com essa questão fundamental acreditamos poder relacionar a atividade de Mário Cláudio, em sua dupla condição de escritor e de pensador do trabalho estético. Em seus livros, por entre o relato sobre as vidas e o diálogo com as obras de suas personagens, insere-se uma 
consoladora ideia da relação do homem com a obra de arte. Por isto, julgamos que, em Rosa, antes de a ceramista poder dedicar-se à criação dos bonecos, não terá sido por acaso que o narrador se refira à sua atividade de sobrevivência como labor: "De igual substância se the compunha o labor, diferentemente assimilado, talvez, preordenado à nutrição, porém, e ao crescimento da prole" (CLÁUDIO, 1988, p. 50). Assim, Rosa, de forma emblemática, sintetizaria, em concordância com o pensamento de Hannah Arendt, o quanto o trabalho artístico pode ser vital e transformador, como certamente o foi para ela e, por diferentes percursos, para Amadeo e para Guilhermina, assim como, certamente, para o escritor que sobre eles escreveu.

\section{REFERÊNCIAS BIBLIOGRÁFICAS}

ARENDT, Hannah. A condição humana. Tradução: Celso Lafer. Rio de Janeiro: Forense-Universitária, 1993.

BAUDELAIRE, Charles. Richard Wagnere "Tannhäuser" em Paris. Tradução: Plínio Augusto Coelho e Heitor Ferreira de Castro. São Paulo: Imaginário:EDUSP, 1990.

BENJAMIN, Walter. O conceito de crítica de arte no romantismo alemão. Tradução: Márcio Seligmann-Silva. São Paulo: EDUSP, 1993.

CALABRESE, Omar. A idade neobarroca. Tradução: Carmen de Carvalho e Artur Morão. Lisboa: Edições 70, 1988.

CLÁUDIO, Mário. Amadeo. 3. ed. Lisboa: Imprensa Nacional/Casa da Moeda, 1986.

Guilhermina. Lisboa: Imprensa Nacional/Casa da Moeda, 1986.

Rosa. Lisboa: Imprensa Nacional/Casa da Moeda, 1988.

CLÜVER, Claus. Estudos interartes: conceitos, termos, objetivos. In: Literatura e Sociedade: de teoria literária e literatura comparada. São Paulo: USP, n. 2, p. 37-55, 1997.

DELEUZE, Gilles. Proust e os signos. Tradução: Antonio Carlos Piquet e Roberto Machado. Rio de Janeiro: Forense-Universitária, 1987.

JUNQUEIRA, Ivan. Introdução: A arte de Baudelaire. In: BAUDELAIRE, Charles. As flores do mal. Tradução: Ivan Junqueira. Rio de Janeiro: Nova Fronteira, 1985.

MERLEAU-PONTY, Maurice. O olho e o espírito. seguido de $A$ linguagem indireta e as vozes do silêncio e A dúvida de Cézanne. Tradução: Paulo Neves e Maria Ermantina Galvão Gomes. São Paulo: Cosac \& Naify, 2004

PAZ, Octavio. Os filhos do barro: romantismo à vanguarda. Tradução:Olga Savary.Rio de Janeiro: Nova Fronteira, 1984.

PESSANHA, José Américo Motta. Bachelard e Monet: o olho e a mão. In: NOVAES, Adauto (org.). O olhar. São Paulo: Companhia das Letras, 1988 , p. $149-165$. 


\section{NOTAS}

1. Em sua primeira versão, este trabalho foi publicado como parte de um dos capítulos do livro de minha autoria Narrativa biográfica e outras artes - reflexões sobre escrita literária e criação estética na Trilogia da Mão, de Mário Cláudio, editado pela EdUFF, em 2008.

2. Referimo-nos às edições iniciais dos romances publicadas pela Imprensa Nacional/ Casa da Moeda. A edição posterior (Dom Quixote, 1993), que reúne em um só volume os três romances, sob o título de Trilogia da Mão, não possui as reproduções das obras dos biografados, nem as suas fotos. 